\title{
9. SILICEOUS SEDIMENTS FROM THE NAURU BASIN: DIAGENETIC ALTERATION OF BIOGENIC OPAL AND AUTHIGENESIS OF SILICA AND SILICATES ${ }^{1}$
}

\author{
Volkher Riech, Bundesanstalt für Geowissenschaften und Rohstoffe, \\ D 3000 Hannover 51, Federal Republic of Germany
}

\begin{abstract}
This study deals with the mineralogical variability of siliceous and zeolitic sediments, porcellanites, and cherts at small intervals in the continuously cored sequence of Deep Sea Drilling Project Site 462. Skeletal opal is preserved down to a maximum burial depth of 390 meters (middle Eocene). Below this level, the tests are totally dissolved or replaced and filled by opal-CT, quartz, clinoptilolite, and calcite. Etching of opaline tests does not increase continously with deeper burial. Opal solution accompanied by a conspicuous formation of authigenic clinoptilolite has a local maximum in Core $16(150 \mathrm{~m})$. A causal relationship with the lower Miocene hiatus at this level is highly probable.

Oligocene to Cenomanian sediments represent an intermediate stage of silica diagenesis: the opal-CT/quartz ratios of the silicified rocks are frequently greater than 1 , and quartz filling pores or replacing foraminifer tests is more widespread than quartz which converted from an opal-CT precursor.

As at other sites, there is a marked discontinuity of the transitions from biogenic opal via opal-CT to quartz with increasing depth of burial. Layers with unaltered opal-A alternate with porcellanite beds; the intensity of the opal-CT-toquartz transformation changes very rapidly from horizon to horizon and obviously is not correlated with lithologic parameters.

The silica for authigenic clinoptilolite was derived from biogenic opal and decaying volcanic components.
\end{abstract}

\section{INTRODUCTION}

Site 462 is in the deep Nauru Basin, surrounded by atolls of the Marshall Islands and volcanic islands of the Caroline chain. The drill penetrated 560 meters of calcareous and siliceous oozes, chalks, limestones, and cherts of Tertiary age, and volcanogenic and zeolitic sandstone, mudstone, and limestone of Maestrichtian to Cenomanian age. Below this sedimentary section we recovered cores from a thick igneous complex with intercalated hyaloclastic mudstones of Aptian to Barremian age. All sedimentary units contain abundant transported and redeposited sediments.

Previous studies on chert from the western, central, and northern Pacific include those by Heath and Moberly (1971), Lancelot (1973), Garrison et al. (1975), Keene (1975, 1976), Kelts (1976) and Hein et al. (1978). Whereas these authors investigated samples from several sites, this study covers only one site. However, Site 462 offered the opportunity to study the mineralogical variability of siliceous and zeolitic sediments and cherts at small intervals in one continuously cored sedimentary sequence.

Instead of a detailed description of silicified sediments, I shall emphasize in this study (1) the behavior of biogenic opal during increasing burial, (2) the mineralogy of porcellanites and cherts, particularly the ratio of opal-CT to quartz and the quartz occurrences with and without detectable opal-CT precursors, and (3) the source materials for the authigenesis of zeolites.

The classification of silicified sediments is based on a semiquantitative estimate of silica mineralogy by optical and/or X-ray-diffraction (XRD) analysis. Hence the

\footnotetext{
${ }^{1}$ Initial Reports of the Deep Sea Drilling Project, Volume 61.
}

term "porcellanite" is used strictly in a mineralogical sense for rocks containing more opal-CT than quartz.

\section{BIOGENIC OPAL IN PLEISTOCENE TO EOCENE SEDIMENTS}

$\mathrm{X}$-ray-amorphous matter occurs in the entire sedimentary column, but biogenic opal (opal-A) is preserved only down to a maximum burial depth of 390 meters in Core 462-41 (middle Eocene). Above Core 41, the contents of X-ray-amorphous material in smectitepoor samples are mostly identical with the amounts of optically determined biogenic opal. Below the abovementioned core, amorphous constituents cannot be equated with biosiliceous components. Unfortunately, the X-ray-diffraction patterns of opal-A and other amorphous constituents could not be distinguished. Opal-A seems to be detectable by XRD analysis only if it exceeds $10 \%$ (as estimated from smear slides). In smectite-rich samples, XRD analysis may yield overestimated percentages of opal-A, because smectite contributes also to the broad "opal hump" between 3 and $6 \AA$, and other X-ray-amorphous matter is more abundant in clayey sediments.

A relatively time-consuming method to study the mineralogy of opaline tests in detail is the measurement of their refractive indexes (Hurd and Theyer, 1977; Riech, 1980). With some experience, in many cases a simple visual inspection of cleaned samples under the microscope is sufficient to decide whether the fossils still consist of the original opal-A or were diagenetically altered to opal-CT. Usually, remains of opal-A have much smoother outlines and surfaces than opal-CT skeletons.

Figure 1 shows the distribution, abundance, and mineralogy of siliceous microfossils. Whereas opal-A- 


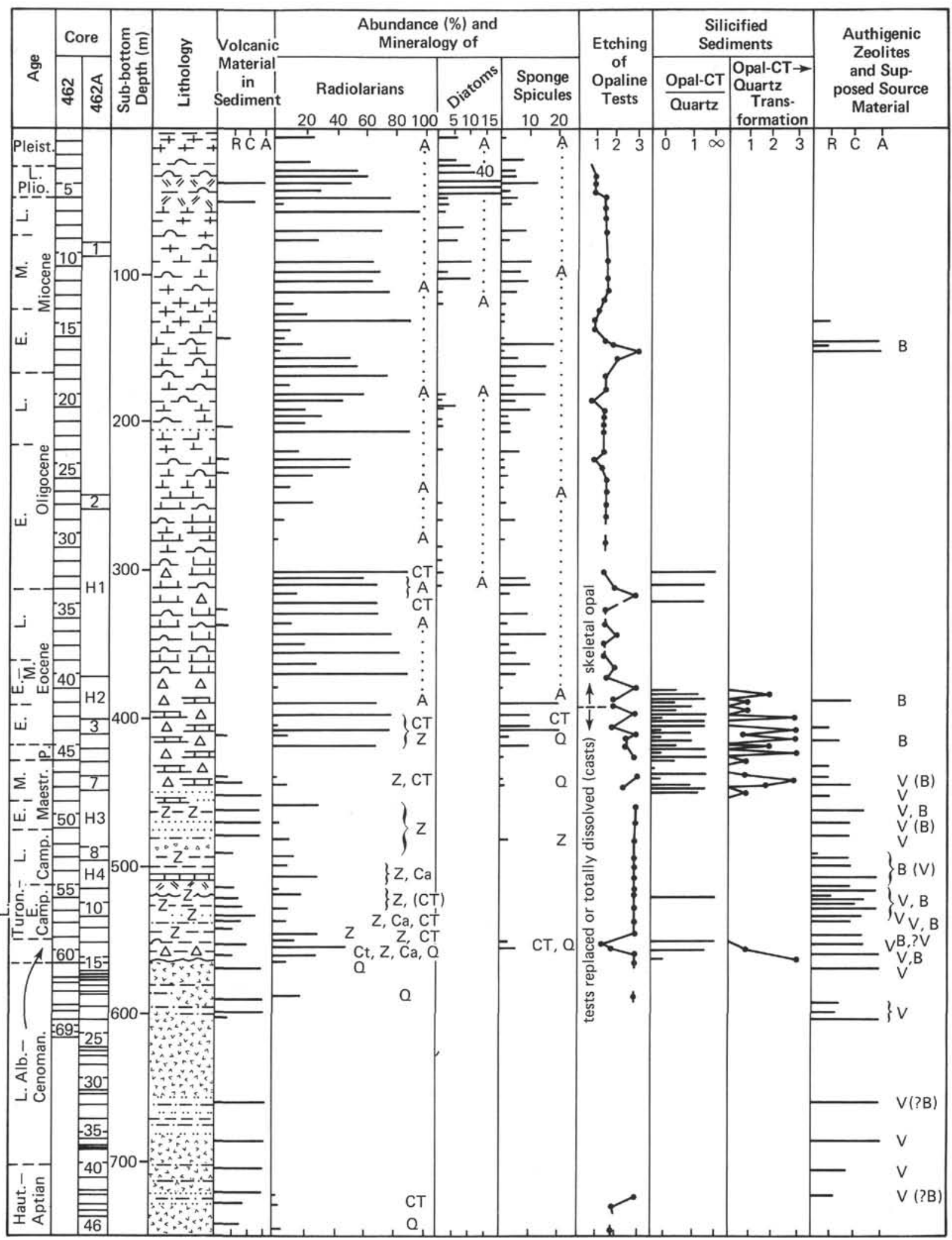

Figure 1. Pattern of silica diagenesis at Site 462 with respect to abundance, mineralogy, and etching of siliceous tests; frequency of volcanic material and authigenic zeolites and their supposed source material; variation of opal-CT-to-quartz ratio in porcellanites and cherts; and the degree of "maturity" of diagenetic silica phases (inversion from opal-CT to quartz). Abbreviations: volcanic material in sediments and authigenic zeolites: $\mathrm{R}=$ rare, $\mathrm{C}=$ common, $\mathrm{A}=$ abundant; $\mathrm{A}=$ opal- $\mathrm{A}, \mathrm{CT}=$ opal-CT, $\mathrm{Q}=$ quartz, $\mathrm{Z}=$ zeolitic casts, $\mathrm{Ca}=$ calcitic casts of radiolarians; $\mathrm{B}=$ biogenic source, $\mathrm{V}=$ volcanogenic source (volcanic glass, etc.) of zeolites; etching of opaline tests: $1=$ weak, $3=$ strong; opal-CT to quartz ratio: $\mathrm{O}=$ pure quartzose cherts, $\infty=$ pure opal-CT porcellanites; opal-CT $\rightarrow$ quartz transformation: $1=$ small amount of opal-CT transformed to quartz, $3=$ completed transformation. Lithologic symbols are explained in the site chapter (this volume). 
preserved radiolarians and sponge spicules are common and abundant down to Core 462-41, the diatoms have only one maximum in Cores 462-3 to 5; they are missing in Cores 462-13 to 17, and occur in lesser amounts between Cores 462-17 and 33. The disappearance of diatoms below the Oligocene/Eocene boundary roughly coincides with the earliest precipitation of significant amounts of opal-CT in porcellanites.

In the studied section of Site 462, the fragmentation of skeletal opal is generally high (Plate 1, Figs. 1 and 2), but does not show a clear correlation with the intensity of opal dissolution. This means that the fragmentation is essentially caused by depositional conditions (e.g., reworking), and not by diagenesis. Nevertheless, compaction and post-burial dissolution have contributed to the extremely high fragmentation of opaline tests in the more deeply buried, semi-consolidated radiolarian oozes. According to sieve analyses, the siliceous oozes between Cores $462-1$ and 17 contain 30 to 50 wt. $\%$ opal $<32$ $\mu \mathrm{m}$, below these cores even 55 to $80 \mathrm{wt}$. $\%$ opal $<32$ $\mu \mathrm{m}$, and only 10 to $30 \mathrm{wt}$. $\%$ opal $>32 \mu \mathrm{m}$.

Although etching of opaline tests is generally more pronounced with increasing burial depth (Fig. 1), it does not increase continuously downward. Distinct etching phenomena are first visible in the section between Cores 462-5 to 11 (Plate 1, Figs.8 and 9). Very strong dissolution of opaline material is restricted to Core 462-16 and is in some levels associated with large amounts of authigenic clinoptilolite (Plate 1, Fig. 6). Shipboard paleontologists suggest a small hiatus within Core $462-15$ or between Cores 15 and 16 (lower Miocene). In contrast to the severely corroded or totally dissolved siliceous assemblage, planktonic foraminifers in Core 16 are surprisingly well preserved, whereas nannofossils also show increased etching (Site Summary, this volume).

Below Core 16, biogenic opal is again abundant down to Core 41 , but is characterized by a solutionresistant association (Plate 1, Fig. 3). Because of its restricted diagenetic stability, opal-A is completely lacking in lower Eocene and older sediments.

\section{SILICIFIED SEDIMENTS}

\section{General Remarks} 462:

Three silicification processes can be studied at Site

1) After a significant proportion of biogenic opal has been dissolved, opal-CT precipitates as cement and replaces nannofossils; in siliceous oozes a considerable part of opal-A converts in situ into opal-CT in a "quasisolid-solid"' microstructural conversion.

2) Simultaneously or shortly later, quartz may crystallize from pore solutions.

3) The last diagenetic step is the transformation of opal-CT into quartz, which is equivalent to the alteration of porcellanites into quartzose cherts.

\section{Host Rocks}

Silicification occurs in all non-volcanogenic rocks of Site 462 . Of 39 silicified rock specimens which I studied in detail, 26 are calcareous with varying admixtures of siliceous organisms, 10 siliceous or clayey-siliceous, and 3 marly-siliceous. The main lithologies of the host sediments are listed in Table 1: the abundance of early-diagenetic quartz indicates how many foraminifers, shallowwater components, or sponge spicules were originally present which are now preferentially replaced by quartz.

\section{Discontinuous Silicification}

At Site 462 we observe a nearly 100 -meter-thick transition zone in lower Oligocene to middle Eocene sediments, in which silicified beds are separated by several meters of unaltered siliceous oozes or opal-bearing chalks. The discontinuity of silicification processes is especially emphasized by the fact that original opal-A is still present in Sample 462-41,CC, whereas a few meters below (Core 42) a quartzose chert occurs in which all opal-CT is already transformed to quartz. This proves that, as in cementation processes in chalks and limestones, silicification phenomena occur in an irregular manner. Opaline sediments do not change into porcellanites or chert at a well-defined age or burial level.

\section{Opal-CT/Quartz Ratios}

The uppermost silicified rocks we encountered were porcellanites at a sub-bottom depth of 300 meters. The source sediment was a compacted siliceous ooze similar to the adjacent sediments, which have a porosity of about $60 \%$. After silicification, the porosity was reduced to $15 \%$, i.e., silica cement filled three fourths of the former pore space. This radiolarian porcellanite now consists of nearly equal amounts of opal-CT which originated in situ from opal-A skeletons and genuine opal-CT cement (compare Figs. 1 and 4, Plate 1).

In 22 of 39 investigated silicified rocks, I found opalCT/quartz ratios $>1$ (Table 1). Thus, opal-CT is generally more abundant than quartz. One fifth of the studied samples are pure quartzose cherts. Only one chert is associated with clayey-siliceous host sediments (in Core 462-60, immediately above the basalt sill), whereas the others have calcareous source rocks. The cherts consist mainly of quartz which recrystallized from on opal-CT precursor. This intermediate phase may be preserved in relics, or can be recognized from quartz-replaced opal-CT spheres (Plate 1, Fig. 5). In two chert samples, no distinct opal-CT $\rightarrow$ quartz inversion is evident but high contents of early-diagenetic quartz are visible (Table 1, Samples $462-40, C C$ and $462-45-1,7-10 \mathrm{~cm})$.

Whereas 28 of my samples contain more than $5 \%$ diagenetic quartz, only 8 specimens show a distinct to complete opal-CT $\rightarrow$ quartz transition. This means that in the recent diagenetic stage quartz replacement of fossils and cementing of pores predominates, and quartz derived from opal-CT is less important.

As shown in Table 1 and Figure 1, the intensity of the opal-CT-to-quartz transformation changes very rapidly in a vertical direction; obviously, it is not correlated with clay or $\mathrm{CaCO}_{3}$ contents or other parameters seen in thin-sections. 
Table 1. Characteristics of silicified sediments at Site 462 according to host-rock lithology, opal-CT-to-quartz ratio, and the origin of the quartz phase.

\begin{tabular}{|c|c|c|c|c|c|c|}
\hline \multirow{2}{*}{$\begin{array}{c}\text { Sample } \\
\text { (interval in } \mathrm{cm} \text { ) }\end{array}$} & \multirow{2}{*}{$\begin{array}{c}\text { Lithology of } \\
\text { Silicified Rock }\end{array}$} & \multicolumn{2}{|c|}{$\begin{array}{l}\text { Main Lithology of } \\
\text { Sediment }\end{array}$} & \multirow{2}{*}{$\begin{array}{c}\text { Abundance } \\
\text { of Early } \\
\text { Diagenetic } \\
\text { Quartz }\end{array}$} & \multirow{2}{*}{$\frac{\text { Opal-CT }}{\text { Quartz }}$} & \multirow{2}{*}{$\begin{array}{c}\text { Stage of } \\
\text { Opal-CT- } \\
\text { Quartz } \\
\text { Transformation }\end{array}$} \\
\hline & & Calcareous & Siliceous & & & \\
\hline $462-32-2,64-66$ & Radiolarian porecellanite & & ++++ & & $\infty$ & \\
\hline 462A-H1,CC & Calcareous porcellanite & ++++ & + & + & $>>1$ & \\
\hline $462-34, C C$ & Radiolarian porcellanite & & ++++ & + & $>>1$ & \\
\hline $462-40, C C$ & $\begin{array}{l}\text { Opal-CT-bearing quartzose } \\
\text { chert }\end{array}$ & ++++ & & +++ & $<1$ & $?$ \\
\hline $462 \mathrm{~A} \cdot \mathrm{H} 2-1,40-43$ & $\begin{array}{l}\text { Porcellanite with quartzose } \\
\text { patches }\end{array}$ & ++++ & + & + & $>1$ & ++ \\
\hline $462 \mathrm{~A}-\mathrm{H} 2-1,55-60(1)$ & $\begin{array}{l}\text { Porcellaneous radiolarian } \\
\text { claystone }\end{array}$ & & ++++ & & $>>1$ & \\
\hline $462 \mathrm{~A}-\mathrm{H} 2-1,55-60(2)$ & $\begin{array}{l}\text { Calcareous quartz-bearing } \\
\text { porcellanite }\end{array}$ & +++ & + & ++ & $>1$ & $?$ \\
\hline $462 \mathrm{~A}-\mathrm{H} 2-1,79-83$ & Radiolarian porcellanite & & ++++ & & $>>1$ & \\
\hline $462 \mathrm{~A}-\mathrm{H} 2-1,131-135$ & $\begin{array}{l}\text { Foraminiferal arenite with } \\
\text { quartzose patches }\end{array}$ & ++++ & & +++ & $<1$ & + \\
\hline $462-42-1,1-4$ & $\begin{array}{l}\text { Foraminiferal limestone } \\
\text { with opal-CT- and } \\
\text { quartz-bearing layers }\end{array}$ & ++++ & & ++ & 1 & \\
\hline $462-42-1,8-10$ & $\begin{array}{l}\text { Calcarenite, partly replaced } \\
\text { and cemented by } \\
\text { opal-CT and quartz }\end{array}$ & ++++ & & +++ & $<1$ & + \\
\hline $462-42-1,24-27$ & $\begin{array}{l}\text { Foraminifer-nannofossil } \\
\text { limestone impregnated } \\
\text { by opal-CT }\end{array}$ & ++++ & & ++ & $<1$ & \\
\hline $462-42-1,42-44$ & Quartzose chert & ++++ & & ++ & 0 & ++++ \\
\hline $462-42-1,51-54$ & $\begin{array}{l}\text { Foraminifer-nannofossil } \\
\text { limestone impregnated } \\
\text { by opal-CT }\end{array}$ & ++++ & + & ++ & $>1$ & \\
\hline $462-43-1,13-15$ & As above & ++++ & + & ++ & $>1$ & \\
\hline $462-43-1,39-41$ & Calcareous porcellanite & ++++ & + & + & $>1$ & \\
\hline $462 \mathrm{~A}-3-1,24$ & Quartzose chert & ++++ & & ++ & 0 & ++++ \\
\hline $462-3-1,23-25$ & $\begin{array}{l}\text { Radiolarian porcelianite } \\
\text { with quartz-replaced } \\
\text { sponge spicules }\end{array}$ & & ++++ & ++ & $>1$ & \\
\hline $462 \mathrm{~A}-3-1,37-39$ & $\begin{array}{l}\text { Foraminiferal arenite with } \\
\text { opal-CT and quartz }\end{array}$ & ++++ & + & +++ & 1 & + \\
\hline $462-44-1,2-4$ & $\begin{array}{l}\text { Foraminiferal limestone } \\
\text { impregnated by opal-CT }\end{array}$ & ++++ & & ++ & $>1$ & \\
\hline $462-4-1,21-23$ & $\begin{array}{l}\text { Foraminiferal limestone } \\
\text { with opal-CT and } \\
\text { quartz }\end{array}$ & ++++ & + & ++ & 1 & \\
\hline $462-44-1,29-32$ & Quartzose chert & ++++ & & +++ & 0 & ++++ \\
\hline $462-44-1,44$ & Opal-CT-bearing limestone & ++++ & + & $?$ & $>>1$ & \\
\hline $462-44-1,66-67$ & Quartzose chert & ++++ & & $?$ & 0 & ++++ \\
\hline $462 A-4-1,2-5$ & Radiolarian porcellanite & & ++++ & ++ & $>1$ & \\
\hline $462 A-4-1,32-36$ & Quartzose chert & ++++ & & +++ & 0 & ++++ \\
\hline $462 \mathrm{~A}-4-1,44-48$ & $\begin{array}{l}\text { Opal-CT-bearing quartzose } \\
\text { chert }\end{array}$ & ++++ & & +++ & $<1$ & +++ \\
\hline $462 \mathrm{~A}-4-1,62-64$ & Marly porcellanite & ++ & ++ & ++ & $>1$ & \\
\hline $462 A-4-1,72-74$ & Marly porcellanite & ++ & ++ & ++ & $>1$ & \\
\hline $462-45-1,7-10$ & $\begin{array}{l}\text { Opal-CT-bearing quartzose } \\
\text { chert }\end{array}$ & ++++ & & +++ & $<1$ & + \\
\hline $462-47, \mathrm{CC}(1)$ & Quartz-bearing porcellanite & ++ & ++ & + & $>1$ & + \\
\hline $462-47, \mathrm{CC}(2)$ & Quartzose chert & ++++ & & +++ & 0 & ++++ \\
\hline $462 A-7-1,5-7$ & Quartz-rich porcellanite & +++ & + & ++ & 1 & ++ \\
\hline $462 \mathrm{~A}-7-1,39$ & Porcellaneous limestone & +++ & + & & $>>1$ & \\
\hline $462 A-7-1,127-129$ & $\begin{array}{l}\text { Porcellaneous foraminifer- } \\
\text { nannofossil limestone }\end{array}$ & ++++ & + & ++ & $>1$ & + \\
\hline $462 \mathrm{~A}-9-1,90$ & $\begin{array}{l}\text { Zeolitic radiolarian clay- } \\
\text { stone with opal-CT }\end{array}$ & & ++++ & & $\infty$ & \\
\hline $462 A-12-1,31-35$ & As above & & ++++ & & $\infty$ & \\
\hline $462-59-1,13-15$ & Radiolarian porcellanite & & ++++ & ++ & $>1$ & + \\
\hline $462 \mathrm{~A}-14-1,120$ & $\begin{array}{l}\text { Quartzose chert, rich in } \\
\text { radiolarians and goethite } \\
\text { (above basalt sill) }\end{array}$ & & +++ & ++ & 0 & ++++ \\
\hline
\end{tabular}

\section{Ordering of the Opal-CT Structure}

At Site 462 the $d(101)$ spacing of opal-CT decreases from $4.13 \AA$ ( $300 \mathrm{~m}$ burial depth) to $4.05 \AA$ ( $560 \mathrm{~m}$ burial depth). This confirms the well-known phenomenon of progressive ordering of the opal-CT structure with increasing age and temperature (see also Murata and $\mathrm{Na}$ kata, 1974; Murata and Larson, 1975; von Rad et al., 1977).

\section{Density and Porosity}

Density and porosity values are mainly available for mixed types of porcellanites and cherts and show a wide scatter. As expected, the values of the few measured pure opal-CT and quartzose varieties show distinct differences:

\begin{tabular}{lcc}
\hline & $\begin{array}{c}\text { Wet-Bulk } \\
\text { Density } \\
\left(\mathrm{g} / \mathrm{cm}^{3}\right)\end{array}$ & $\begin{array}{c}\text { Porosity } \\
(\%)\end{array}$ \\
\hline Porcellanites & $2.07-2.12$ & $13.2-17.7$ \\
Quartzose cherts & $2.50-2.68$ & $0.9-5.2$ \\
\hline
\end{tabular}

\section{Relationship between Carbonate and Silica Diagenesis}

Van der Lingen and Packham (1975) investigated the carbonate sequence of the Ontong-Java plateau and suggested that silica diagenesis affects carbonate diagenesis, because "the replacement of calcite by silica must result in calcium carbonate enrichment outside the chert nodule." Likewise, at Site 462 a mutual influence can be recognized. In Cores $462-42$ to 47 , strong silici- 
fication results in increasing $\mathrm{CaCO}_{3}$ cementation of interbedded chalks and limestones. Furthermore, smear slides show that below 300 meters burial depth, where the first porcellanites occur, the ratio of identifiable nannofossils to unspecified carbonate particles decreases, and in the main cherty interval the unspecified carbonate predominates. Below this level of widespread silica precipitation, nannofossils are again better preserved.

\section{ZEOLITIC SEDIMENTS}

$\mathrm{X}$-ray-diffraction analyses of 13 zeolitic samples from various lithologies constantly yielded clinoptilolite as the only zeolite. Maximum percentages with up to $90 \%$ clinoptilolite occur in zeolitic claystones which were originally rich in radiolarians. This is evident from poorly recognizable zeolitic fillings of dissolved radiolarian skeletons, whereas in these beds alteration products of volcanic origin are lacking or of minor importance. However, it has to be admitted that sometimes a differentiation between former volcanic and biosiliceous components in altered zeolitized sediments is impossible.

The youngest sediments containing an abundant admixture of clinoptilolite occur in Core 462-16. As mentioned earlier, several horizons with strong dissolution of biogenic opal occur in this core. In addition to zeolitic radiolarian casts, clinoptilolite usually forms tiny, poorly developed prisms (Plate 1, Fig. 6). The zeoliterich beds (up to $60 \%$ clinoptilolite) in Core 16 coincide with the minimum of opal-A-preserved skeletons. In levels of lesser corrosion, there are only trace amounts of zeolites. Because a few horizons with nearly complete dissolution of opal do not contain any clinoptilolite, the degree of corrosion is not necessarily correlated with the formation of zeolite.

Although clinoptilolite in Core $462-16$ is associated with (dissolved) siliceous organisms, most of the radiolarian-rich porcellanites do not show this mutual occurrence. In general, zeolites are only sporadically distributed in the cherty zone (Fig. 1); this is also true for opal-CT in the zeolite-rich sequence below 450 meters. Consequently, the distribution of authigenic silica is relatively independent of that of clinoptilolite. This is in contrast with many other DSDP occurrences (e.g., Stonecipher, 1976; Hein et al., 1978; Riech, 1980).

Zeolites appear mainly in the volcanogenic section between the basalt sill and the cherty zone, and in some intra-basalt mudstones. The zeolitic sediments represent the alteration products of volcaniclastic siltstones and sandstones, tuffaceous bioarenites, vitric tuffs, ashy marlstones, hyaloclastites, radiolarian clays, and nannofossil limestones with admixtures of radiolarians and volcanic components. Frequently, small zeolite prisms form the matrix together with authigenic smectite. In siltstones or sandstones, larger clinoptilolite crystals occur (Plate 1, Fig. 7), which grew in open cavities. At certain levels, clayey, calcitic, or zeolitic radiolarian casts are common in volcanogenic sediments. Furthermore, there are some bluish-green and brown beds of zeolitic claystone, only a few centimeters thick, which are interpreted as the products of background pelagic sedimentation and probably were very rich in radiolarians before zeolitization (e.g., in Cores 462-49, 52, 53, 54, 55,$58 ; 462 \mathrm{~A}-9,11$, and 12 ).

\section{AUTHIGENIC CLAY MINERALS}

The following comments on the distribution and origin of clay minerals at Site 462 are based on X-raydiffraction analyses of 45 sediment samples (H. Rösch, Hannover). Smectite is the most abundant clay mineral; it occurs throughout the sedimentary sequence. According to Eslinger and Savin (1976) and Hein and Scholl (1978), the average percentage of expandable layers in the illite/smectite of a sample is a clue to the origin of this mineral. Our analyses confirm that the Tertiary sequence of Site 462 contains mostly detrital illite/smectite $(l / h: 0.36-0.70)$, whereas in the Cretaceous sediments with abundant volcanic parent material authigenic smectite appears to be more frequent $(l / h: 0.71-0.89)$.

Palygorskite occurs in larger proportions only in the volcanic sequence (e.g., in Cores 462-51, 55, and 462A10). The genesis of palygorskite in deep-sea sediments is still somewhat enigmatic (Weaver and Beck, 1977; Couture, 1978). In this case, it is possible that the hydrous magnesium silicate originated from degraded montmorillonitic clays in the presence of magnesium-and silica-rich solutions derived from the decay of volcanic particles and radiolarians.

\section{CONCLUSIONS}

\section{Paleoenvironment and Silica Diagenesis}

During the northwestward motion of the Pacific Plate, the area of Site 462 reached the equatorial zone of high productivity $\left(\sim 5^{\circ} \mathrm{S}\right)$ approximately at the beginning of the Eocene, and remained between $5^{\circ} \mathrm{S}$ and $5^{\circ} \mathrm{N}$ until the late Miocene (compare Lancelot and Larson, 1975, fig. 1). The crossing is marked by sediments rich in siliceous microfossils. Nevertheless, radiolarians were deposited in significant amounts already in Cenomanian times at a paleolatitude of 25 to $30^{\circ} \mathrm{S}$, causing the formation of the oldest cherts at Site $\mathbf{4 6 2}$.

In comparison with the DSDP sites in the northwestern Pacific (Leg 32), the Cretaceous at Site 462 is comparatively poor in "cherts." This might be explained by synchronous volcanism and the accumulation of abundant volcaniclastic material and basalts in the Nauru Basin during Cretaceous times: during the alteration of volcanic particles and the authigenesis of smectite and zeolites, less free silica is available to form porcellanites and cherts.

The deposition of abundant calcareous turbidites in this deep-sea environment below the CCD did not fundamentally influence chert diagenesis in the Oligocene to Maestrichtian section. However, in some layers the calcareous matrix accelerated conversion of porcellanites to quartzose cherts, and foraminifers and calcareous shallow-water debris were preferably replaced by quartz.

\section{Pre- and Post-Burial Dissolution of Opal}

The maximum opal solution above the chert horizon in Site 462 occurs in Core 16. A causal relationship be- 
tween the complete disappearance of opaline skeletons due to pre-burial solution, the lower Miocene hiatus, and the formation of authigenic clinoptilolite is highly probable. This finding appears to be an exception to the statistically proved correlation between clinoptilolite and moderate to high sedimentation rate in the host sediments at many DSDP sites (Stonecipher, 1976).

The possibility of post-burial and deposition- independent influences is very unlikely, because of the sudden increase of opal solution in this core and the occurrences of better-preserved skeletons below this level. Von Stackelberg (1979) detected a similar relationship near a widespread Miocene/Pliocene hiatus in the equatorial Pacific southeast of Hawaii with high amounts of radiolarian casts and newly formed phillipsite. Riedel (1959) attributed the poor preservation or absence of siliceous microfossils to low sedimentation rates. In a detailed study of the dissolution of radiolarians in sediments of the Ontong-Java plateau, Holdsworth and Harker (1975) found that some periods of intensified corrosion were probably periods of non-deposition and/or erosion.

During the dissolution of opaline components in the uppermost layers of a sedimentary sequence, either the silica-enriched waters escape more or less completely into the oceanic bottom water, or some dissolved silica is consumed to form authigenic silicates such as zeolites or smectite (Johnson, 1976). No formation of such minerals is expected if biogenic opal is dissolved immediately at the sediment surface or during redeposition. Most probably, clinoptilolite, phillipsite, or smectite form only in sediment-covered layers which allow the pore waters to become enriched in silica and delay the flux of solutions into the overlying bottom waters. The alternation of dissolution levels with and without clinoptilolite in Core 462-16 can be explained by different sediment covers during the solution of opal and formation of zeolites, but the mechanisms of zeolite formation near the water/sediment interface during periods of low sedimentation or nondeposition are still poorly understood.

A few radiolarian porcellanites are enriched in fish remains, as are horizons of strong opal dissolution in Core 462-16. This indicates low sedimentation rates. A genetic connection between unconformities pre-burial opal dissolution, and formation of porcellanites is not supported by DSDP evidence. The best prerequisite for significant post-burial silicification is a moderate to high sedimentation rate, which favors preservation of biogenic silica, before diagenetic corrosion starts (Riech and von Rad, 1979a).

The disappearance of biogenic opal below Core 46241 resembles the supposed pre-burial dissolution of siliceous microfossils in Core 16. Unfortunately, in sediments of increasing age and/or deeper burial it becomes more and more difficult to differentiate between preburial and post-burial corrosion of opal, because postburial dissolution masks a possible earlier stage of etching. In Core 41 and below, diagenetic dissolution processes are probably more important; this is indicated by the strong silicification of these horizons. According to our experience from the Atlantic Ocean, biogenic opal may be preserved in middle Eocene sediments down to a burial depth of 600 to 700 meters, but in many cases the opal-A $\rightarrow$ opal-CT conversion takes place at shallower depths, so that the fact that opal-A at Site 462 is buried nearly 400 meters fits well in the age-depth diagram of silica phases from the Atlantic Ocean (Riech and von Rad, 1979b, fig. 11).

\section{Opal-CT/Quartz Ratios of Silicified Sediments}

A semiquantitative estimate of the opal-CT/quartz ratio is sufficient to describe the mineralogy of silicified rocks. In addition, the genesis of quartzose components has to be optically analyzed to avoid misinterpretation of the diagenetic history of "cherts.' It seems important to differentiate between early diagenetic quartz and recrystallized quartz which originated in situ from an opalCT precursor. In general, the opal-CT/quartz ratio is continuously reduced to lower values with proceeding diagenesis.

During silicification, the opal-CT/quartz ratio is essentially controlled by the original sedimentary components and the quantity and size of pores or voids. Opal$\mathrm{CT}$ is usually the first silica cement. Because the crystallites and spheres are small, they fill only micropores (e.g., within a nannofossil matrix) and marginal parts of larger voids. Oozes composed of highly fragmented opaline debris, as at Site 462, are converted to porcellanites with extremely high opal-CT/quartz ratios. Quartz crystallizes in the central parts of fossil pores or other larger cavities; it replaces foraminifer tests, calcitic fragments of shallow-water debris, and sponge spicules. Therefore, foraminiferal arenites and radiolarian oozes with many complete radiolarians (i.e., many fossil voids) and/or sponge spicules are rich in quartz, precipitated during early diagenesis. Opal-CTcemented nannofossil oozes, clays and sediments with broken radiolarian debris do not leave any pore space for the crystallization of chalcedony. In these sediments, quartz occurs only after it is converted from opal-CT in a later diagenetic process.

In the actual diagenetic stage, the opal-CT/quartz ratios of the silicified rocks at Site 462 increase frequently to more than 1 , and early diagenetic quartz is still more widespread than quartz which converted from an opal-CT precursor. Thus, an intermediate stage of silica diagenesis is indicated in the Oligocene to Cenomanian sediments, although in a few horizons the "maturation" of metastable opal-CT to stable quartz is already completed. According to Heath (1973) and Keene (1975), opal-CT also predominates in carbonate-rich sediments of Legs 16 and 32, whereas Lancelot (1973) postulated that, in general, calcareous environments favor precipitation of quartz. Doubtless the main lithologies influence the opal-CT/quartz ratio, especially during late diagenesis. The conversion of opal-CT to quartz is accelerated in calcareous host sediments, and retarded in clays. This is also confirmed by our studies of Site 462 material. In contrast to the experimental data of Kastner et al. (1977), the opal-A $\rightarrow$ opal-CT transformation appears not to be significantly accelerated in 
the carbonates of the Nauru Basin. However, the authors also state that because of different rates of diffusion of $\mathrm{CO}_{2}$ out of the system the acceleration of opal-A diagenesis in carbonate layers is not necessarily observed.

\section{Influences of Age and Temperature on Silica Transformations}

In addition to facies, sediment age and depth of burial or temperature are the most obvious factors influencing the rate of chertification. In Figure 2, the present depth of the youngest sediment with authigenic silica is plotted against age for many Pacific DSDP sites. In general, the sediment age seems to be a more important diagenetic factor than burial depth. The Miocene porcellanite occurrences in the marginal basins of the Pacific (area encircled by dashed line in Fig. 2) are exceptions, because high heat flow and/or high amounts of less-resistant diatoms accelerate the precipitation of opal-CT (Keene, 1976). Even in these cases, a minimum age of $10 \mathrm{~m} . \mathrm{y}$. is often necessary to initiate silicification. At least 25 m.y. pass after the deposition of opal-bearing sediments before silicified rocks form in the central regions of the Pacific. In addition to age and burial depth, we have to take into account highly different heat-flow values, varying sediment types, and other unknown parameters controlling silica diagenesis. There-

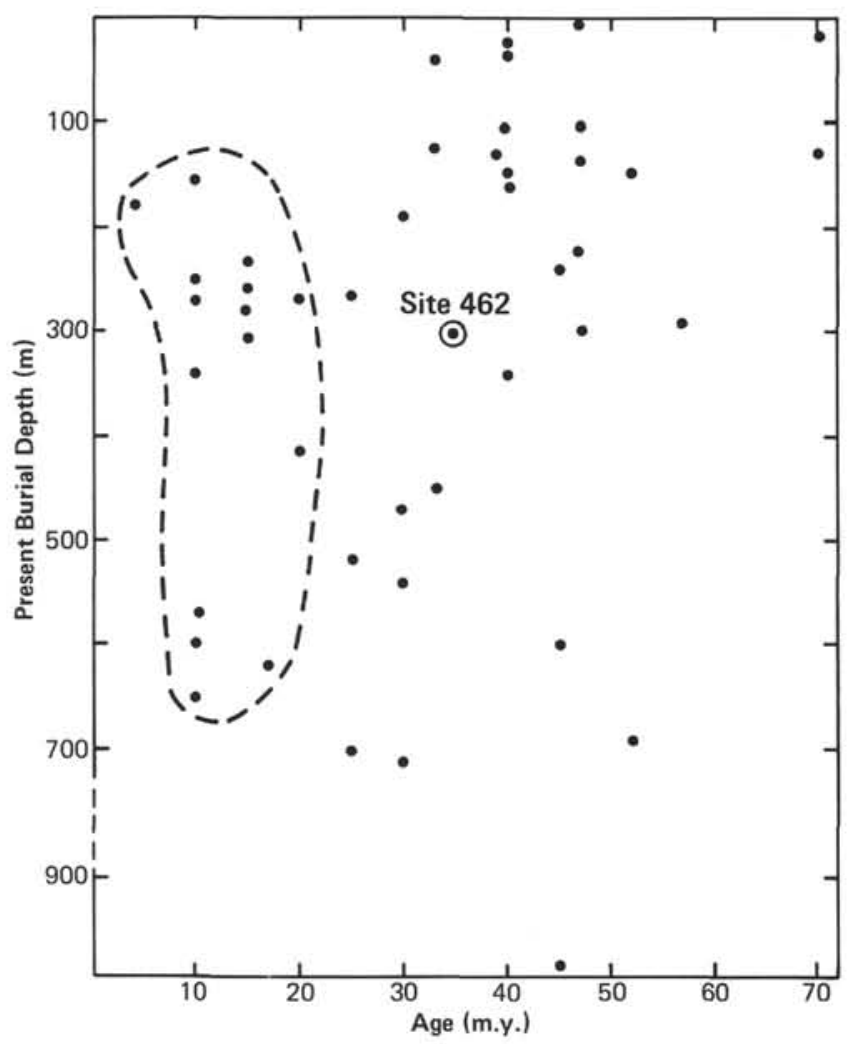

Figure 2. Present depth of burial of the youngest Pacific sediment containing authigenic silica (DSDP Legs 5-9, 16-21, 30-33, 35, 61, and 63). Sites at which no sediments with biogenic silica overlie the silicified horizons and sites with a major disconformity were omitted. fore, we see no clear correlation between sediment age and depth of burial of the young porcellanites (Fig. 2).

In the claystones of Site 462, no quartzose chert was expected, because it is well known that clayey matrix significantly retards the conversion of opal-CT to quartz. During the formation of the very dense and tough chert in Core 462-60 immediately above the basalt sill, the retarding effect of the clay minerals was probably compensated by the thermal influence of the intrusion, which accelerated crystallization of quartz from the opal-CT precursor.

\section{The Problem of Discontinuous Silicification with Increasing Depth of Burial}

We have briefly discussed the possible influences of sediment age, depth of burial or temperature, and lithology on the transformation rates of the silica phases. Nevertheless, in many cases the marked discontinuity of the transitions from opal-A via opal-CT to quartz with increasing depth of burial is a puzzling problem. At Site 462 , this is especially obvious at the level of Cores $462-41$ and 42 , where layers with mineralogically unaltered opal-A alternate with porcellanite beds, and even with one quartzose chert. Below this section, we observe again strong fluctuations in the degree of the opal-CT $\rightarrow$ quartz conversion: calcareous porcellanites alternate with calcareous cherts (Table 1; Fig. 1), and there is no evidence that simple lithological factors, such as the carbonate or clay content, are responsible for the differences.

Apparently, we can apply the concept of the "diagenetic potential,' originally developed for ooze-chalklimestone sequences (Schlanger and Douglas, 1974), also to the diagenetic evolution of siliceous deposits. These authors postulate that variation in the degree of cementation (plotted as a function of burial depth) is caused by initial variations in the diagenetic potential of the original sediment, so that chalks (porcellanites) can form above oozes (siliceous oozes), and limestones (cherts) above chalks (porcellanites) in the sedimentary column. According to Schlanger and Douglas (1974), the diagenetic potential of the sediment is in large part predetermined by oceanographic conditions prior to burial. The same holds true for siliceous plankton, which may produce several varieties of opal (Goll and Bjørklund, 1972; Hurd and Theyer, 1977), reacting in a different manner under post-burial conditions.

\section{The Genesis of Zeolites}

In contrast to authigenic silica at Site 462 , the silica for zeolites can be derived from biogenic opal and volcanic components (Fig. 1). This means that clinoptilolite is not a typical product of decaying volcanic material, and does not clearly indicate a biogenic origin (compare also Kastner and Stonecipher, 1978).

Surprisingly, the radiolarian sediments below a burial depth of 450 meters are rarely transformed into "cherts"' (e.g., in Cores 462-59 and 60), but mostly into zeolitic claystones. This might be explained by the high ratio of volcanic to opaline material. The diagenetic decay of volcanic material concentrates metal ions in the 
pore waters, which favors the crystallization of morecomplex silicates. Possibly the admixture of opaline material (pure silica) in the volcanogenic sequence supported the formation of silica-rich clinoptilolite and prevented authigenesis of the less-silica-rich zeolites (e.g., phillipsite) in noticeable amounts.

\section{ACKNOWLEDGMENTS}

I am especially grateful to U. von Rad (Hannover), who reviewed the manuscript and suggested essential improvements. H. Rösch (Hannover) carried out X-ray-diffraction analyses and gave advice on the interpretation of these data. This paper was also kindly reviewed by M. Kastner. Financial support from the German Research Society (DFG grant $\mathrm{Ra} 191 / 8$ ) is gratefully appreciated.

\section{REFERENCES}

Couture, R. A., 1978. Comments on: Miocene of the S.E. United States: a model for chemical sedimentation in a peri-marine environment (Weaver and Beck). Sed. Geol., 21:149-154.

Eslinger, E. V., and Savin, S. M., 1976. Mineralogy and $\mathrm{O}^{18} / \mathrm{O}^{16}$ ratios of fine-grained quartz and clay from Site 323. In Hollister, C. D., Craddock, C., et al., Init. Repts. DSDP 35: Washington (U.S. Govt. Printing Office), 489-496.

Garrison, R. E., Rowland, St. M., Horau, I. J., et al., 1975. Petrology of siliceous rocks recovered from marginal seas of the western Pacific, Leg 31, Deep Sea Drilling Project. In Karig, D. E., Ingle, J. C., et al., Init. Repts. DSDP, 31: Washington (U.S. Govt. Printing Office), 519-529.

Goll, R. M., and Bjørklund, K. R., 1972. Radiolaria in surface sediments of the North Atlantic Ocean. Micropaleont., 17:434 454.

Heath, G. R., 1973. Cherts from the eastern Pacific. In van Andel, Tj. H., Heath, G. R., et al., Init. Repts. DSDP, 16: Washington (U.S. Govt. Printing Office), 609-613.

Heath, G. R., and Moberly, R., 1971. Cherts from the western Pacific, Leg 7, Deep Sea Drilling Project. In Winterer, E. L., Riedel, W. R., et al., Init. Repts. DSDP, 7, Pt. 2: Washington (U.S. Govt. Printing Office), 991-1008.

Hein, J. R., and Scholl, D. W., 1978. Diagenesis and distribution of Late Cenozoic volcanic sediment in the southern Bering Sea. Geol. Soc. Am. Bull., 89:197-210.

Hein, J. R., Scholl, D. W., Barron, J. A., et al., 1978. Diagenesis of late Cenozoic diatomaceous deposits and formation of the bottom simulating reflector in the southern Bering Sea. Sedimentol., 25:155-181.

Holdsworth, B. K., and Harker, B. M., 1975. Possible indicators of degree of Radiolaria dissolution in calcareous sediments of the Ontong-Java Plateau. In Andrews, J. E., Packham, G., et al., Init. Repts. DSDP, 30: Washington (U.S. Govt. Printing Office), 489-495.

Hurd, D. C., and Theyer, F., 1977. Changes in the physical and chemical properties of biogenic silica from the central equatorial Pacific: Part II. Refractive index density and water content of acid-cleaned samples. Am. J. Sci., 277:1168-1202.

Johnson, T. C., 1976. Biogenic opal preservation in pelagic sediments of a small area in the eastern tropical Pacific. Geol. Soc. Am. Bull., 87:1237-1282.

Kastner, M., Keene, J. B., and Gieskes, J. M., 1977. Diagenesis of siliceous oozes. I. Chemical controls on the rate of opal-A to opalCT transformation-an experimental study. Geochim. Cosmochim. Acta, 41:1041-1059.

Kastner, M., and Stonecipher, S. A., 1978. Zeolites in pelagic sediments of the Atlantic, Pacific, and Indian Ocean. In Sand, L. B., and Mumpton, F. A. (Eds.), Natural Zeolites: New York (Pergamon Press), pp. 199-220.

Keene, J. B., 1975. Cherts and porcellanites from the North Pacific, Deep Sea Drilling Project Leg 32. In Larson, R. L., Moberly, R., et al., Init. Repts. DSDP, 32: Washington (U.S. Govt. Printing Office), 429-507.

1976. The distribution, mineralogy and petrography of biogenic and authigenic silica from the Pacific Basin [Ph. D. dissert.]. Scripps Inst. Oceanogr., San Diego.

Kelts, K., 1976. Summary of chert occurrences from Line Island Sites $314,315,316$, DSDP Leg 33. In Schlanger, S. O., Jackson, E. D., et al., Init. Repts. DSDP, 33: Washington (U.S. Govt. Printing Office), 855-863.

Lancelot, Y., 1973. Chert and silica diagenesis in sediments from the central Pacific. In Winterer, E. L., Ewing, J. I., et al., Init. Repts. DSDP, 17: Washington (U.S. Govt. Printing Office), 377-405.

Lancelot, Y., and Larson, R., 1975 Sedimentary and tectonic evolution of the northwestern Pacific. In Larson, R. L., Moberly, R., et al., Init. Repts. DSDP, 32: Washington (U.S. Govt. Printing Office), 925-939.

Murata, K. J., and Larson, R. R., 1975. Diagenesis of Miocene siliceous shales, Tembler Range, California. J. Res. U.S. Geol. Surv., 3:553-566.

Murata, K. J., and Nakata, J. K., 1974. Cristobalitic stage in the diagenesis of diatomaceous shale. Science, 18:567-568.

Riech, V., 1980. Diagenesis of silica, zeolites and phyllosilicates at Sites 397 and 398. In von Rad, U., Ryan, W. B. F., et al., Init. Repts. DSDP, 47, Pt. 1: Washington (U.S. Govt. Printing Office), 741-760.

Riech, V., and von Rad, U., 1979a. Eocene porcellanites and Early Cretaceous cherts from the western North Atlantic. In Tucholke, B., Vogt, P. R., et al., Init. Repts. DSDP, 43: Washington (U.S. Govt. Printing Office), 437-455.

1979b. Silica diagenesis in the Atlantic Ocean: diagenetic potential and transformations. In Talwani, M., Hay, W., and Ryan, W. B. (Eds.), Deep Drilling Results in the Atlantic Ocean. Continental Margins and Paleoenvironment: Washington (Am. Geophys. Union), pp. 98-107.

Riedel, W. R., 1959. Siliceous organic remains in pelagic sediments. In Ireland, H. A. (Ed.), Silica in sediments: Soc. Econ. Paleont. Mineral. Spec. Pub., 7:80-91.

Schlanger, S. O., and Douglas, R. G., 1974. Pelagic ooze-chalk-limestone transition and its implications for marine stratigraphy. In Hsü, K. J., and Jenkyns, H. C. (Eds.), Pelagic Sediments: On Land and under the Sea: Spec. Pub. Int. Assoc. Sedimentol., $1: 117-148$.

Stonecipher, S. A., 1976. Origin, distribution and diagenesis of phillipsite and clinoptilolite in deep-sea sediments. Chem. Geol., 17:307-318.

van der Lingen, G. J., and Packham, G. H., 1975. Relationships between diagenesis and physical properties of biogenic sediments of the Ontong-Java Plateau (Sites 288 and 289, Deep Sea Drilling Project). In Andrews, J. E., Packham, G., et al., Init. Repts. $D S D P, 30$ : Washington (U.S. Govt. Printing Office), 443-481.

von Rad, U., Riech, V., and Rösch, H., 1977. Silica diagenesis in continental margin sediments off Northwest Africa. In Lancelot, Y., Seibold, E., et al., Init. Repts. DSDP, 41: Washington (U.S. Govt. Printing Office), 879-905.

von Stackelberg, U., 1979. Sedimentation, hiatuses and development of manganese nodules (Valdivia Site VA 13/2, Northern Central Pacific). In Bischoff, J. L., and Piper, D. Z. (Eds.), Marine Geology and Oceanography of the Central Pacific Manganese Nodule Province: New York (Plenum), pp. 555-587.

Weaver, C. E., and Beck, K. C., 1977. Miocene of the S.E. United States: a model for chemical sedimentation in a peri-marine environment. Sediment. Geol., 17:1-234. 

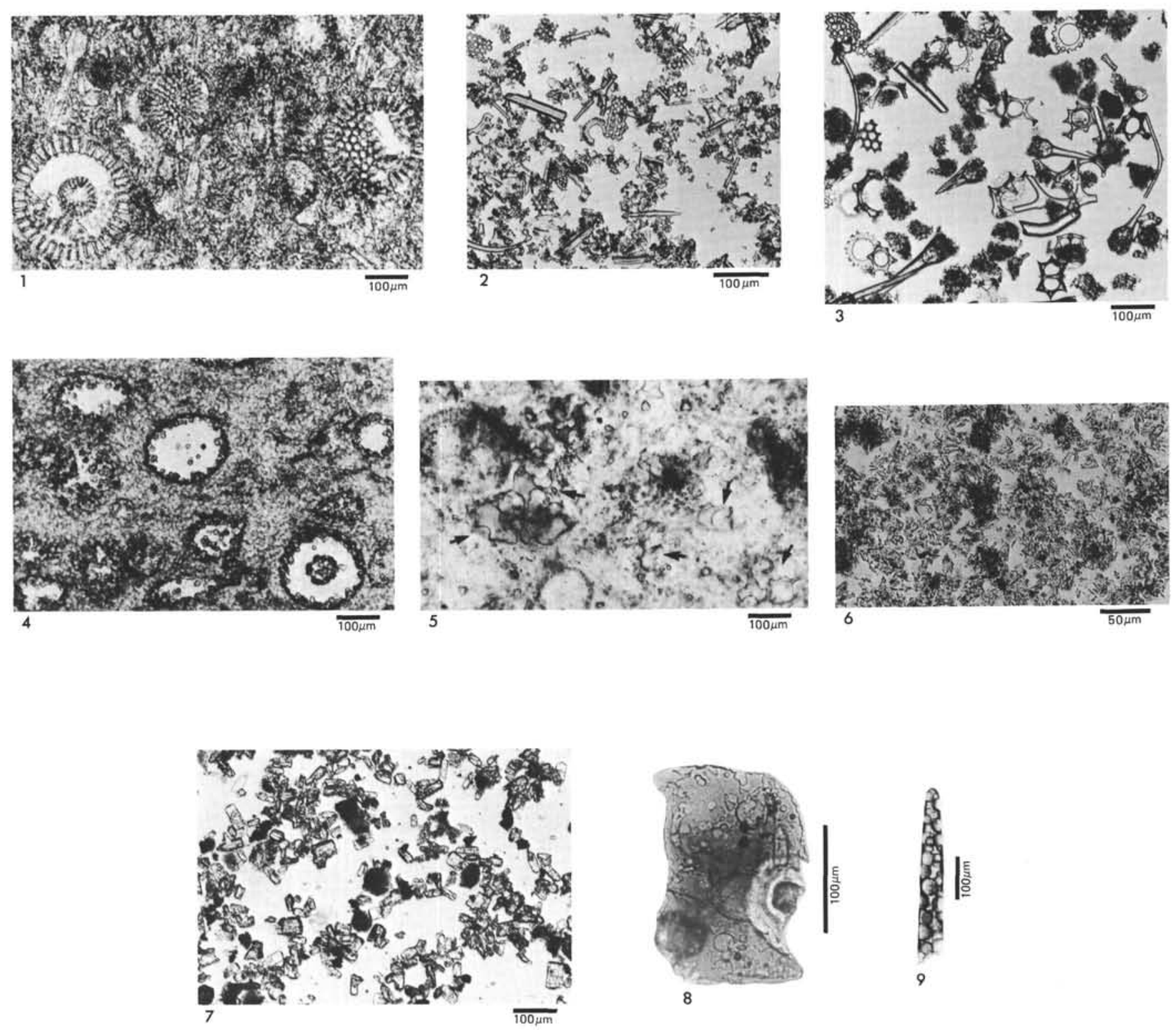

Plate 1. Photomicrographs.

Figure 1. Sample 462-38-1, 28-29 cm (355 m; late Eocene); photomicrograph of an undisturbed firm radiolarian ooze; between few unfragmented spumellarian tests the matrix is composed of highly fragmented opaline particles; the diagnetic alteration is restricted to a slight compaction of the ooze and to partial dissolution of the biogenic opal; there is a total lack of authigenic silica cement and no mineralogical alteration of the original opal-A to other silica phases.

Figure 2. Sample 462-39-1, 125-127 cm (365 m; early-middle Eocene); smear slide of the $<32-\mu \mathrm{m}$ size fraction of a siliceous ooze; $60 \mathrm{wt}$. $\%$ of the bulk sample is composed of opaline particles in this size; because of common reworking at Site 462 , fragmentation of siliceous shells is high.

Figure 3. Sample 462-17-5, 77-79 cm (160 m; early Miocene), significant dissolution of delicate opaline components results in a siliceous assemblage of heavy-shelled fragments of radiolarians and sponge spicules (see also Fig. 9).

Figure 4. Sample 462A-4-1, 2-5 cm (412 m; early Eocene); thin-section of a radiolarian porcellanite; matrix is smectite-bearing opal-CT which originated from highly fractured opaline particles similar to those occurring in the ooze of Figure 1; clear radiolarian cavities are filled by tiny lepispheres of opal-CT and (mostly) chalcedony.

Figure 5. Sample 462-44-1, 29-32 cm (410 m; early Eocene); quartzose chert replacing foraminifer limestone. Note relict opal-CT spheres (arrows), now transformed to chalcedony which lines the former walls of foraminifer chambers.

Figure 6. Sample 462-16-4, 135-137 cm ( $150 \mathrm{~cm}$; early Miocene); more than half of this zeolitic clay (smear slide of the $<32-\mu \mathrm{m}$ fraction) is composed of tiny, badly developed clinoptilolite prisms; extremely corroded and dissolved siliceous assemblages in many samples of Core 16 can be explained by low sedimentation rates; in this case all biogenic opal is dissolved, which resulted in strong crystallization of clinoptilolite.

Figure 7. Sample 462A-7-1, 86-89 cm (440 m; middle Maestrichtian); $\mathrm{HCl}$-residue of altered tuffaceous biocalcarenite with abundant clinoptilolite; in contrast to the biogenic precursor material of zeolites in Figure 6, a mainly volcanic source is highly suggested in this sample.

Figure 8. Sample 462-6-1, 99-101 cm ( $50 \mathrm{~m}$; late Miocene); glass shard from ashy nannofossil ooze with solution pits; associated radiolarians and sponge spicules are also slightly corroded.

Figure 9. Sample $462-5-4,80-82 \mathrm{~cm}$ (45 m; late Pliocene), sponge spicule from siliceous nannofossil ooze, with very distinct solution pits. 